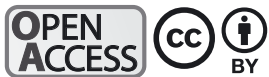

\section{Hawksbill nest site selection affects hatchling survival at a rookery in Antigua, West Indies}

\author{
Megan Reising ${ }^{1}$, Michael Salmon ${ }^{1, *}$, Seth Stapleton ${ }^{2,3}$ \\ ${ }^{1}$ Department of Biological Sciences, Florida Atlantic University, Boca Raton, Florida 33431, USA \\ ${ }^{2}$ Jumby Bay Hawksbill Project, St. John's, Long Island, Antigua, West Indies \\ ${ }^{3}$ Department of Fisheries, Wildlife and Conservation Biology, University of Minnesota, St. Paul, Minnesota 55108, USA
}

\begin{abstract}
Nesting populations of Critically Endangered hawksbill sea turtles remain depleted across much of their range in the Caribbean. Some islands, however, including Jumby Bay (Pasture Bay) in Antigua, have shown a steady increase in the number of nesting females. Furthermore, in recent years nesting has occurred in particularly high densities within the remnant maritime forest on the northwestern side of the bay, concentrating the entry of emerging hatchlings into the sea along a small ( $160 \mathrm{~m}$ long) length of shoreline. Previous studies have shown that when many hatchlings enter the sea from a restricted location, aquatic predators may exploit that site. We followed 49 hatchlings by kayak at night as they swam offshore, and we determined that predation rates were significantly higher on the western than on the eastern side of the bay. At both locations, the turtles showed no obvious differences in offshore orientation that might have increased their vulnerability to predators. We hypothesize that the greater predation rate was most likely caused by the presence of more predators. To reduce those predation pressures, we recommend a 2-pronged strategy: (1) 'risk-spreading' (releasing hatchlings at other locations adjacent to, and within, the bay), and (2) habitat restoration to expand the area of attractive nesting habitat.
\end{abstract}

KEY WORDS: Hawksbill $\cdot$ Eretmochelys $\cdot$ Predation $\cdot$ Nest density $\cdot$ Management $\cdot$ Predator-prey interactions

\section{INTRODUCTION}

Current estimates indicate a $90 \%$ decline in worldwide populations of the hawksbill turtle Eretmochelys imbricata in all major oceans over the last $100 \mathrm{yr}$ (Mortimer \& Donnelly 2008). The causes are well known. This species has been hunted for food, for its eggs, and for its strikingly mottled shell plates. Its feeding grounds in tropical coral reef habitats are threatened by pollution and climate change, and its nesting sites are being altered and compromised to support tourism and other varieties of coastal development. In spite of efforts over many years to conserve and protect this species, their numbers in most locations continue to decline (Meylan \& Donnelly 1999, Mortimer \& Donnelly 2008).

\footnotetext{
*Corresponding author: salmon@fau.edu
}

However, protection has resulted in some population increases, particularly in parts of the Caribbean (e.g. Beggs et al. 2007, NMFS 2007). One such population is found in Pasture Bay, Antigua, where researchers began monitoring turtles via saturation tagging in 1987. This population has more than doubled from $\sim 30$ females in late the 1980s to $\sim 70$ in 2012 , and the number of nests has increased from $\sim 110$ to more than 250 annually over the same period (Jumby Bay Hawksbill Project [JBHP] Annual Reports, at www.jbhp.org). This increase has been brought about not only by the return of experienced females, but also by the addition of new recruits recognized by the absence of tags or tag scars. Currently, over 200 nests each year are marked and, after the hatchlings emerge, over 100 nests are exca-

() The authors 2015. Open Access under Creative Commons by Attribution Licence. Use, distribution and reproduction are unrestricted. Authors and original publication must be credited. 
vated to determine clutch size and productivity (Richardson et al. 1999, 2006, Ditmer \& Stapleton 2012). Hatching success (the proportion of the clutch that produces hatchlings) is high, averaging $78 \%$ (Ditmer \& Stapleton 2012).

Pasture Bay is a U-shaped cove, facing north-northeast. Historically, a maritime forest was located behind the beach but most of that habitat has been removed except for one portion along the shoreline on the northwestern side of the bay. Since 1987 when the JBHP began keeping records, the pattern of nest distribution along the beach has varied as landscape conditions have changed (JBHP, unpubl. reports). That variation is apparently correlated with shifts in the distribution of beach sands and the formation of embankments due to tidal surges, storms and hurricanes, and changes in the vegetation planted behind the beach. Over the years, most of the nesting has occurred within the remnant maritime forest (which represents $<30 \%$ of the available nesting areas inside the Bay) and within a mixture of cultivated and native vegetation in an adjacent beach site facing north. Hawksbills, unlike most species of marine turtles, typically nest under a vegetation canopy (Horrocks \& Scott 1991, Pérez-Castañeda et al. 2007). Over the last $6 \mathrm{yr}$, hawksbills have placed 35 to $>50 \%$ of their nests within the forest (JBHP Annual Reports 2007-2012). Our hypothesis was that such a concentration of nests, and ultimately of hatchlings from those nests entering the sea from a restricted area, attracted aquatic predators and led to higher predation rates.

This hypothesis was reinforced by reports of what can happen when managers deliberately concentrate nests in an effort to protect them from terrestrial threats such as predators, artificial lighting or poachers (Stancyk 1982, Wyneken \& Salmon 1994, Andrews et al. 2003). Managers transfer clutches of eggs to adjacent, safer beach sites where they are reburied, sometimes inside fenced or guarded enclosures. These 'hatcheries' may contain hundreds of nests reburied side by side on the same evening. At the end of incubation some 50 to $60 \mathrm{~d}$ later, hatchlings can emerge from several nests on the same evening and enter the sea from the same location, seaward of the hatchery. Protection as a management objective breaks down if predators locate those areas, presumably through learning. When this happens, the area in front of a hatchery can become a 'feeding station' where predators wait and where fewer turtles survive (Wyneken \& Salmon 1994, Mortimer 1999, Pilcher et al. 2000).

In this study, our goal was to determine whether the concentration of nests in the maritime forest was correlated with an increase in predation rates on hatchlings swimming offshore; the opposite (eastern) side essentially served as a control since fewer turtles nested there. Pasture Bay is ideal for such an assessment as it is small enough to quantify survival rates for swimming hatchlings released from different locations. We also investigated whether there might be alternative explanations for any observed differences in predation rate based on when, seasonally, the nests were deposited or how accurately the hatchlings oriented toward deep water. Turtles that orient poorly are likely to spend more time in shallow water where they are more vulnerable to predators (Whelan \& Wyneken 2007). Our results indicated that predation rates were significantly elevated on the western side of the bay.

\section{MATERIALS AND METHODS}

\section{Study site}

This study was completed between July and September 2012, at Pasture Bay, Long Island (hereafter Jumby Bay), Antigua, West Indies $\left(17^{\circ} 09^{\prime} \mathrm{N}\right.$, $61^{\circ} 45^{\prime} \mathrm{W}$; Fig. 1). Pasture Bay is U-shaped and bordered by a $\sim 650 \mathrm{~m}$ long beach that extends to 2 points: Pasture Point to the west and Homer Point to the east (Fig. 1). The beach is backed by lowlying vegetation dominated by 4 species: seagrape Cocoloba uvifera, inkberry Scaevola sericea, coconut palm Cocos nucifera, and green buttonwood Conocarpus erectus. The far northwest side of the beach contains the last remnants of the original maritime forest.

We completed transects across the bay to quantify depth, to locate reefs that could provide shelter for potential predators, and to identify those predators that were most likely to take hatchlings swimming offshore (Stancyk 1982, Gyuris 1994, Pilcher et al. 2000, Stewart \& Wyneken 2004). The outer transect was made by swimming slowly on a straight path between Pasture and Homer points. Observers used snorkeling gear and dove occasionally to the bottom to inspect coral patches. Depth (water surface to sand bottom) was measured from a kayak travelling on the same path using a weighted line that was marked at $1 \mathrm{~m}$ intervals. Measurements were made at 4 locations, spaced equally between the points and the center of the bay. We made similar and parallel transects at 2 additional locations approximately $1 / 3$ and $2 / 3$ of the distance closer to the shore. 


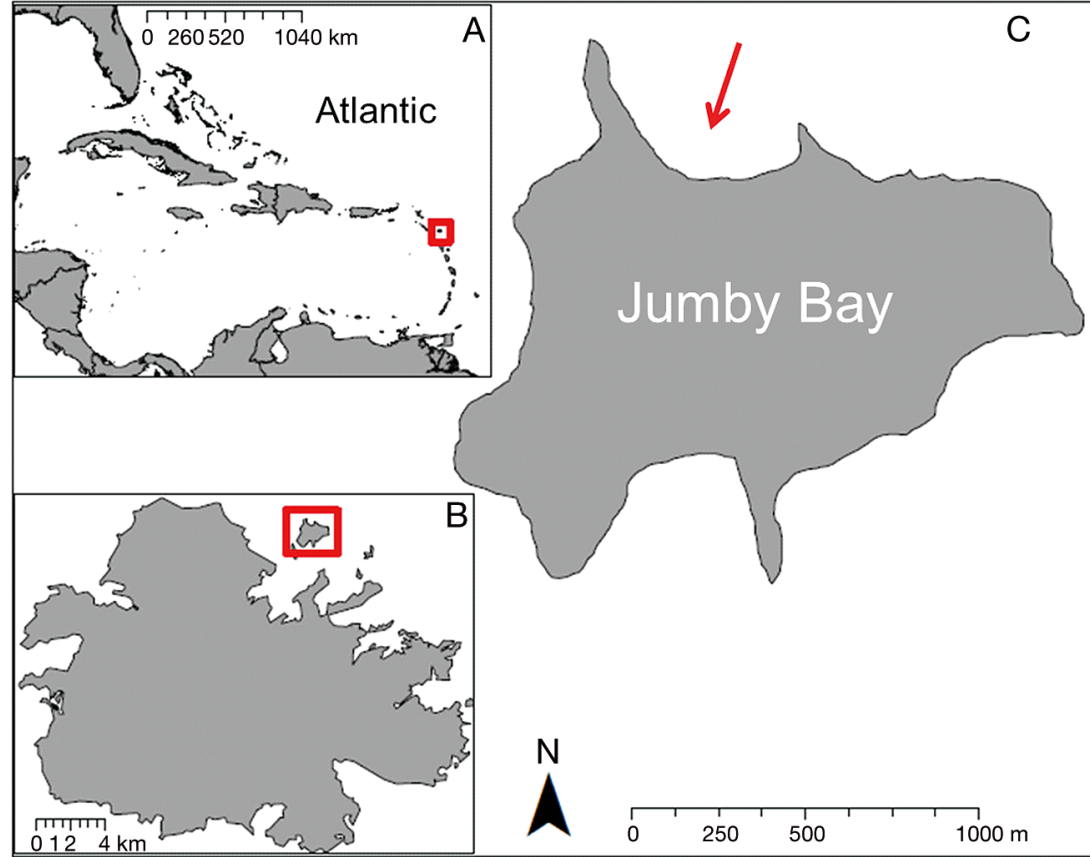

Fig. 1. (A) Antigua in the northeastern Caribbean. (B) The island of Jumby Bay is located $\sim 2 \mathrm{~km}$ to the north of the main island. (C) Pasture Bay (arrow) is a Ushaped cove that ends at Pasture Point to the west and Homer Point to the east

in lunar illumination, water clarity, tidal phase or cloud cover.

Each hatchling towed a 'Witherington float' that consisted of a $5 \times$ $1 \mathrm{~cm}$ wide balsa wood rod, carved into a streamlined shape (Stewart \& Wyneken 2004, Whelan \& Wyneken 2007). A short $(2.4 \mathrm{~cm}$ long) cold-chemical glow stick was glued into a cavity on top of the float. A counterweight attached to the bottom of the float kept the glow stick facing upward so its glow was visible only from above the water. The float was tethered to the turtle by a $\sim 1.5 \mathrm{~m}$ length of lightweight black thread that encircled the hatchling just behind the front flippers. In previous studies, this device failed to attract predators and only slightly reduced hatchling swimming speed (Pilcher et al. 2000, Stewart \& Wyneken 2004). It is unlikely that tracking via the float system compromised hatchling survival, as even unen-

\section{Hatchling collection}

Hatchlings were collected during August and September. We placed plastic coated wire screening around nests that had been incubating for $\sim 55 \mathrm{~d}$ to contain the hatchlings after an emergence. We monitored screened nests at half-hour intervals between 17:00 and 03:00 $\mathrm{h}$. When an emergence occurred we released all of the turtles with the exception of 2 hatchlings that were retained so they could be followed to measure predation rates as they swam offshore.

\section{Measuring predation rates}

Hatchlings were followed offshore by kayak to estimate predation rates. Trials took place within minutes after an emergence occurred (between 17:00 and 03:00 h) and were almost equally divided between those that were staged on the west and on the east side of the bay (Fig. 2). Up to 4 turtles were followed each night when weather permitted (light wind, small waves). One group of turtles was tracked on the east and the other on the west side of the bay. This procedure minimized the probability that predation rates were influenced by nightly differences cumbered marine turtle hatchlings are incapable of swimming faster than their aquatic predators. Floats towed $\sim 10 \mathrm{~m}$ behind the kayak for $0.5 \mathrm{~h}$ at night (as a

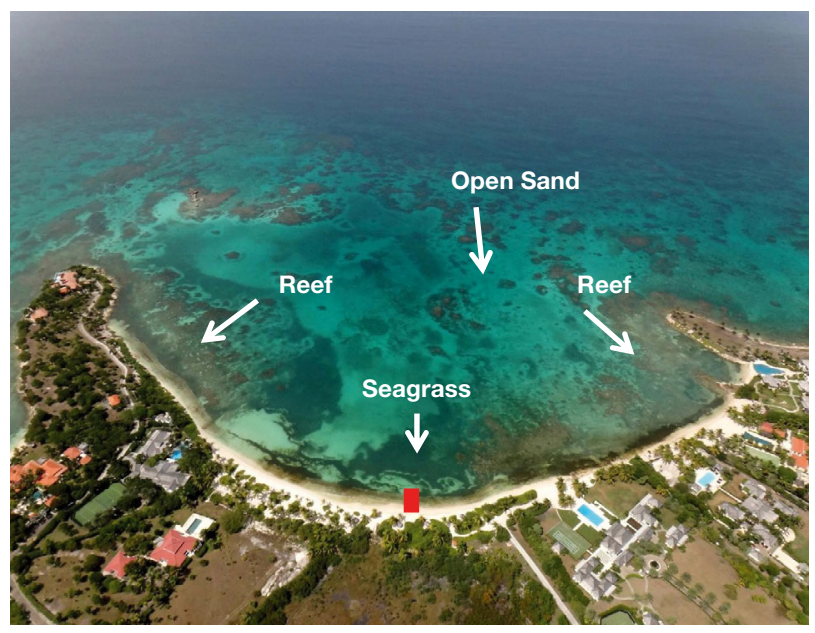

Fig. 2. Aerial view of Pasture Bay, August 2012. Arrows: regions of reef near the shoreline, seagrass beds (primarily Thalassia testudinum) near the center shoreline, the open sand bottom in deeper water with clumps of coral interspersed, and in some instances rising above the water surface at low tide. Red rectangle: division of the shoreline into 2 approximately equal east and west halves. The remnant maritime forest is located on the northwest side of the bay 
test) were not attacked by predators, nor did any predators attack the float shortly before, during or after attacking a hatchling.

Once fitted with the tether and float, each hatchling was allowed to crawl down the beach (with the float held in the air above and behind the turtle), enter the bay, and begin swimming. Turtles were followed by kayak at a distance of 5 to $10 \mathrm{~m}$. A handheld GPS (Garmin Geko 201TM, accuracy: $\pm 3 \mathrm{~m}$ ) was used to record hatchling location at 5 min intervals. Each turtle was followed until it either left the bay, was an estimated $400 \mathrm{~m}$ offshore, had been swimming for at least $30 \mathrm{~min}$, or was taken by a predator. Surviving hatchlings were recaptured, untied and released.

Hatchling fate (taken by a predator or survived its trial) was noted on a battery-powered voice recorder along with the turtle's final GPS location, the approximate depth, a brief description of the bottom habitat, and the duration of the turtle's swimming activity. If the turtle was taken by a predator, the float was usually recovered nearby at the surface with the thread severed.

Our null hypothesis was that there would be no difference in predation rates on hatchlings released on the 2 sides of the bay. This hypothesis was rejected when $\chi^{2}$ test $p$-values were $\leq 0.05$ (Siegel \& Castillan 1988).

\section{Swimming speeds and offshore orientation}

Predated hatchlings were typically consumed too soon after release to accurately measure their swimming speed; speeds were therefore determined using data from the surviving hatchlings. Speeds $\left(\mathrm{m} \mathrm{min}^{-1}\right)$ were calculated by dividing the distance $(\mathrm{m})$ each turtle had travelled by the time spent swimming. Values were converted from $\mathrm{m} \mathrm{min}^{-1}$ to the more typically used $\mathrm{km} \mathrm{h}^{-1}$ to facilitate comparisons with other studies.

Hatchling offshore orientation was determined by the compass direction between the site where the turtle entered the water and its location when the trial ended (either by its release or by its disappearance after being taken by a predator). We used Oriana 3 (Kovach Computing Services) to calculate a group mean angle and dispersion (95\% confidence limit) for the turtles released on each side of the bay. Rayleigh tests (Zar 1999) were used to determine if the 2 groups of turtles preferred to swim in a generally similar direction (e.g. were significantly oriented).

\section{RESULTS}

\section{Site characteristics}

Pasture Bay is deepest $(\leq 4 \mathrm{~m})$ at the center of the transect made farthest offshore between the bay's 2 points. The bay becomes progressively shallower along the 2 parallel transects located $1 / 3$ and $2 / 3$ of the distance toward the shore (Fig. 2). Large patches of mostly dead coral border the shallows on either side of the bay; many smaller patches are scattered inside the bay, with the tops of some exposed during low tide. A limestone bed varying in width is present in the shallows near shore, and is covered with seagrass (primarily Thalassia testudinum; Fig. 2) near the center of the shoreline.

We completed several daytime surveys in an effort to identify and count any fish (or other) predators that might take hatchlings, but none were seen.

\section{Spatial pattern of nest placement}

A total of 211 nests were deposited in Pasture Bay between June and November, distributed as 62 nests in the eastern half and 149 nests in the western half. The number of nests in each half differed significantly from equivalence $\left(105.5, \chi^{2}=17.8, \mathrm{p}<0.001, \mathrm{df}=1\right)$.

\section{Predation rates and associated observations}

We followed 49 hatchlings (25 hatchlings released from the west and 24 released from the east side of the bay) as they swam offshore (Fig. 3). On the western side, 3 hatchlings survived (predation rate = $88 \%$ ) whereas on the eastern side 18 hatchlings survived (predation rate $=25 \%$ ). Predation rates were significantly higher on the west side of the bay (Fisher exact test $\mathrm{p}<0.05$ ).

Tracking was done when sea state conditions inside the bay were either calm (no wind) or when light winds (from the N, NE or SE) generated small waves ( $\leq 30 \mathrm{~cm}$ in height) that did not interfere with observations or kayak maneuverability. Tidal amplitudes in Antigua $(\leq 30 \mathrm{~cm})$ are small and were unlikely to affect predation rates. Hatchlings were most often taken by predators over reefs ( $\mathrm{n}=19 \mathrm{obs}$ ); less often they were taken over sand, seagrass or mixed sand/reef bottom profiles ( $\mathrm{n}=9$ obs). Predation sites varied in distance from the shoreline between 17 to $301 \mathrm{~m}$, and in time from the onset of swimming between 2 min $58 \mathrm{~s}$ and $27 \mathrm{~min}$. On aver- 

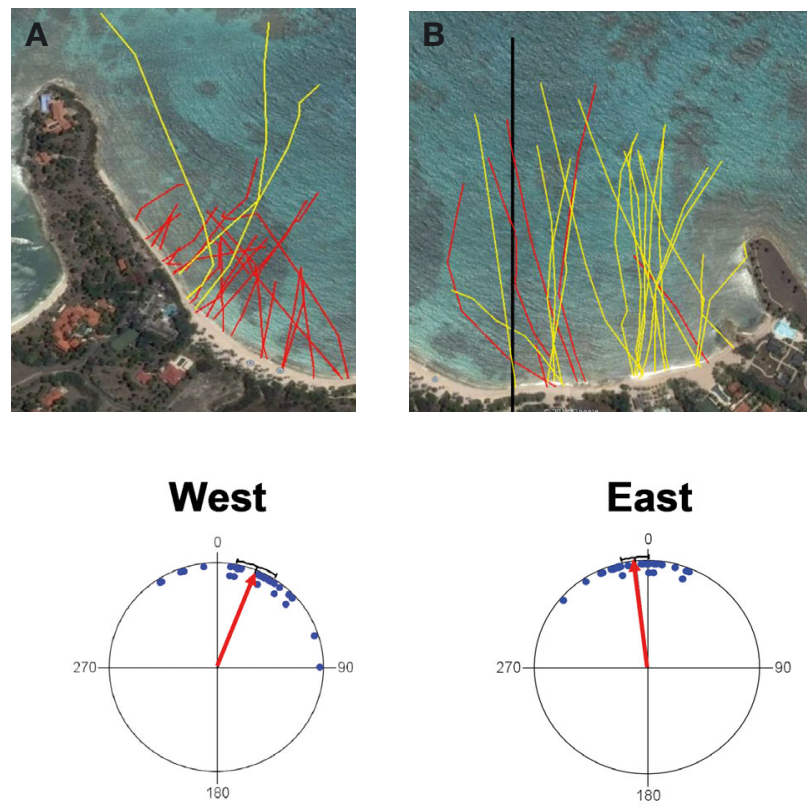

Fig. 3. $(\mathrm{A}, \mathrm{B})$ Paths taken by hawksbill hatchlings as they swam offshore from (A) the west $(n=25)$ and $(B)$ east $(n=24)$ side of Pasture Bay, shown separately for greater clarity. Black line in (B) divides the bay into approximately equal west and east halves. Red tracks represent hatchlings taken by predators. Circle diagrams in bottom panels show the orientation of the turtles in each group: north $\left(0^{\circ}\right)$, east $\left(90^{\circ}\right)$, south $\left(180^{\circ}\right)$, west $\left(270^{\circ}\right)$. Blue dots = single turtles. Arrows point to the group mean angle. Both groups are significantly oriented (Rayleigh test $\mathrm{p}<0.01$ ). Photos: Google Earth

age, predation events occurred after the turtles had been swimming for slightly over $11 \mathrm{~min}$. Predation sites varied in depth between $30 \mathrm{~cm}$ and $3.7 \mathrm{~m}$, with an average depth of $1.7 \mathrm{~m}$.

\section{Swimming speeds and orientation}

Swimming speeds of 18 hatchlings that survived their trial on the east side of the bay averaged $12.4 \mathrm{~m}$ $\min ^{-1}$ (range: $5.0-17.7 \mathrm{~m} \mathrm{~min}^{-1}$ ), or $0.74 \mathrm{~km} \mathrm{~h}^{-1}$ (Fig. 4). Speeds for the 3 turtles that survived on the west side of the bay averaged $14.1 \mathrm{~m} \mathrm{~min}^{-1}$ (range: 13.22-14.95 $\mathrm{m} \mathrm{min}^{-1}$ ), or $0.85 \mathrm{~km} \mathrm{~h}^{-1}$.

Hatchlings oriented in directions that would enable most of the turtles to exit the bay (Fig. 3). The mean angle $( \pm \mathrm{SD})$ on the east side of the bay was slightly west of north $\left(354^{\circ} \pm 10^{\circ}\right)$, whereas on the west side it was northeast $\left(21^{\circ} \pm 7^{\circ}\right)$. Both groups showed nearly identical significant group orientation (Rayleigh test, east: $Z=22.8$,west: $Z=20.4, \mathrm{p}<0.01$; Fig. 3) but no overlap between their $95 \%$ confidence limits, indicating that the 2 distributions differed statistically.

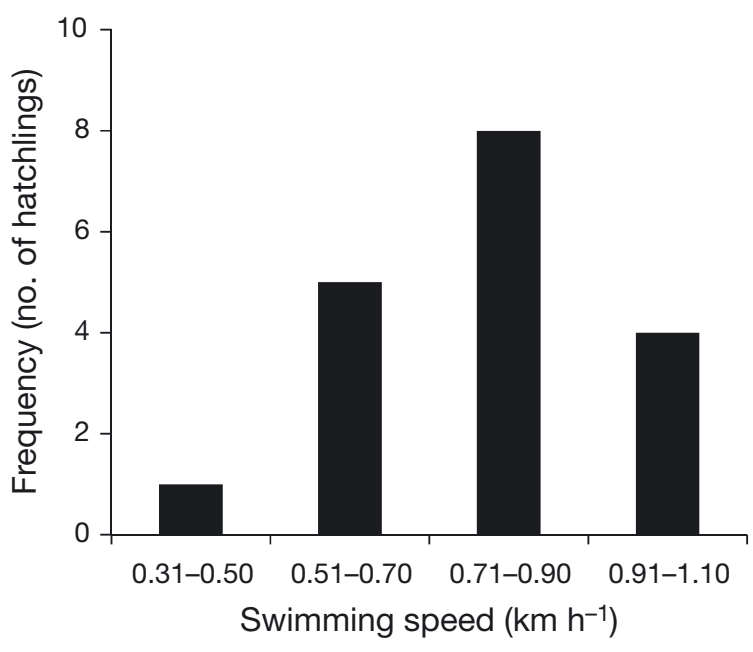

Fig. 4. Distribution of swimming speeds shown by the 18 surviving hawksbill hatchlings released on the east side of Pasture Bay. Mean swimming speed of the 3 surviving turtles released from the west side of the Bay was $0.85 \mathrm{~km} \mathrm{~h}^{-1}$

\section{DISCUSSION}

\section{Factors affecting predation rates}

Predators took most of the hatchlings released from the western side of the bay whereas the majority of the turtles released from the eastern side survived. Several variables could potentially explain these results.

One possibility was that predation rates on the hatchlings differed because turtles on the western side oriented on an offshore course to exit the bay less accurately than the turtles on the eastern side of the bay. The swimming paths of hatchlings exposed to artificial lighting, for example, show more dispersion from a heading directly offshore than those of hatchlings swimming away from dark beaches (Witherington 1991). Under such circumstances, hatchlings spend more time in shallow water, increasing the probability that they will be detected from below by predators (Gyuris 1994, Wyneken \& Salmon 1994, Whelan \& Wyneken 2007). At Pasture Bay, those possibilities appeared remote for several reasons. First, the bay is so shallow that if predators were present, no path in an offshore direction would enable the turtles to evade detection (Fig. 2). Second, most of the hatchlings swimming offshore on both sides of the bay were well oriented (suggesting artificial lighting from homes on the east side of the bay had no major impact on their performance) and showed relatively little deviation from paths that would ultimately lead them out of the bay and toward deep water (Figs. $2 \& 3$ ). 
A second possibility is that the hatchlings released on each side of the bay differed in their swimming speeds, which in turn somehow affected their vulnerability. Although we lack the data to exclude this possibility (because so few turtles on the western side of the bay survived long enough to obtain a reliable swimming speed measurement), this also seems unlikely. The turtles often pulled the same floats. Given the number of turtles tested $(\mathrm{n}=49)$ over a span of several weeks, it is also unlikely that the distribution of swimming speeds differed by chance. At the same time, swimming speed could have been a minor factor that affected turtle survival on the west side of the bay. The 3 survivors on the west side swam at an average speed $\left(0.85 \mathrm{~km} \mathrm{~h}^{-1}\right)$ that was faster than the average speed of the surviving turtles on the east side $\left(0.74 \mathrm{~km} \mathrm{~h}^{-1}\right.$; Fig. 4$)$. This leads us to hypothesize that faster movement through an area containing many predators may be important for achieving even a small increase in survival probability on the western side of the bay. This was not the case on the eastern side as both slower as well as faster swimming turtles survived (Fig. 4).

Additional observations suggest that factors other than swimming speed more importantly influenced the probabilities of hatchling survival. On the east side of the bay, 4 of the 6 turtles taken by predators were lost in relatively deep, more open water after swimming for a longer portion of their trial period. In contrast, most of the turtles taken by predators on the west side of the bay were lost soon after their trial began, and in relatively shallow water (Fig. 3). Those differences, again, suggest a stronger correlation between hatchling fate and location than between hatchling fate and swimming speed.

We conclude that the elevated predation rate on the west side of Pasture Bay was most likely a consequence of a concentration of hatchlings (both in time as well as in space) at a location where predators could capture more prey. Our observations do not permit us to say whether the predators were responding to prey abundance; they may have favored the west side of the bay for other reasons. We can, however, state that the greater abundance of prey on the west side of the bay occurred because a majority of the nests (109 of 211) were placed within the remnant maritime forest, and that this situation ultimately compromised the survival of the hatchlings. We hypothesize that as a result, more predators were attracted to that site, as has been reported to occur under similar conditions in shallow waters in front of hatcheries (Wyneken \& Salmon 1994, Mortimer 1999, Pilcher et al. 2000).
At a hatchery site in southeastern Florida, USA, tarpon Megalops atlanticus, mangrove snapper Lutjanus griseus, yellowtail jack Caranx hippos and reef squid Sepioteuthis sepioidea were common predators of hatchling loggerhead sea turtles Caretta caretta. As was the case at Jumby Bay in the present study, none of these predators were seen in the area during the day. However, all made an appearance in front of the hatchery after dusk where they consumed the turtles, often within minutes after they entered the sea (Wyneken \& Salmon 1994).

\section{Management implications}

At some locations in the Caribbean, the numbers of adult, subadult, and juvenile hawksbills seen on the foraging grounds are increasing (Puerto Rico, Florida, and the US Virgin Islands, NMFS 2007), as are the numbers of nesting females at some key index sites where long-term data are available. Among these are Barbados, Buck Island Reef National Monument, Mona Island, and Jumby Bay, Antigua (Beggs et al. 2007, Richardson et al. 1999, 2006, NMFS 2007). These encouraging results suggest that hawksbill populations can recover when adequately managed and protected.

On their foraging grounds, Caribbean populations of hawksbills consist of genetically mixed stocks that differ in their mtDNA, and thus represent distinct matrilines (Bass 1999, Abreu \& Leroux 2007, NMFS 2007, Leroux et al. 2012, Proietti et al. 2014). When the time comes to breed, females segregate and migrate with strong fidelity to specific regional nesting sites. The genetic stock nesting in Pasture Bay was originally identified by Bass (1999) as unique to rookeries located at Antigua and Barbuda. It thus qualifies as a unique matriline that should be maintained to preserve the genetic diversity of hawksbill populations nesting in the Caribbean Sea.

Interestingly, while the number of females nesting in Pasture Bay and at peripheral beaches on Jumby Bay has increased over the years (Richardson et al. 2006, JBHP Annual Reports 2009-2012), hawksbill nesting elsewhere in Antigua remains depleted (Fuller et al. 1992, Meylan 1999, M. Clovis-Fuller, Antigua Sea Turtle Project, pers. comm.). Unless those trends are reversed, the females nesting at Pasture Bay may represent the only source of new recruits to this matriline. Those circumstances suggest the need for a conservative management strategy, one that promotes an increase both in produc- 
tive adult nesting and in hatchling survival of this Critically Endangered species (Meylan \& Donnelly 1999).

Our data indicate that hatchling survival at Pasture Bay might be compromised, but the evidence that such a reduction in hatchling numbers has a serious impact remains uncertain. Some of the ambiguities center on the following issues:

(1) Since this is the first study of its kind at Pasture Bay, we do not know whether the predation rates we witnessed in 2012 are typical of other years, and especially of those years when nests were differently distributed among the 2 halves. Continued monitoring will be essential to firmly establish the relationship between nest distribution patterns, predator distribution, and predation rates upon the hatchlings.

(2) We do not know if predation rates based upon tracks of single hatchlings are representative of those of hatchlings taken by predators while swimming offshore as a group with their siblings. The latter is the more typical situation for most marine turtles, including hawksbills (Witzell 1983), since hatchlings emerge from their nests in one large or in several smaller groups.

To date, all studies have quantified predation rates on single hatchlings as they are followed offshore (Witherington \& Salmon 1992, Gyuris 1994, Pilcher et al. 2000, Stewart \& Wyneken 2004, Whelan \& Wyneken 2007, Harewood \& Horrocks 2008). When those rates are relatively low $(\leq 6 \%$; e.g. Stewart \& Wyneken 2004, Whelan \& Wyneken 2007, Harewood \& Horrocks 2008) predation rate estimates are likely to be reliable because few predators are present. In contrast, where predation rates are higher (e.g. Gyuris 1994, Pilcher et al. 2000, present study), groups of turtles swimming together might affect more predators (perhaps positively, negatively, or not at all) as a result of a 'dilution effect' (Cresswell \& Quinn 2011) or a 'confusion effect' (Ioannou et al. 2008). Until appropriate experiments are done, the nature of such effects remains unknown. Predation rates may also depend upon the kinds of predators as these may differ in specific strategies used to detect and capture prey, as well as in the number of prey each predator is capable of consuming on a given evening (small squid probably take a single hatchling, whereas each tarpon can consume many turtles; Wyneken \& Salmon 1994).

(3) Another uncertainty centers on what constitutes an 'acceptable' versus an 'unacceptable' loss of hatchlings to predators, from the perspective of population recovery. We know that '...inputs from both [egg and hatchlings stages] are critical to maintain recruitment to the older stages' (Heppell et al. 2003, p. 287), and so a complete loss of all of the hatchlings departing from the bay will not sustain the population. At the same time, ' ...valid input values for Caribbean hawksbills are simply not yet available' (Crouse 1999, p. 186). Our results suggest that the rookery at Pasture Bay remains productive, as nests placed on the eastern side of the bay may contribute disproportionately to the number of hatchlings that survive to exit the bay. Are those numbers adequate to compensate for the losses to predators we describe here? Do the larger clutches of Antigua hawksbills (mean: 144 eggs per nest; JBHP Annual Report for 2012) make this possible? The steady increase in nesting activity over the years at Jumby Bay is encouraging and suggests a positive answer. However, it is unclear whether the benefits accrue only to sites on Jumby Bay; mainland (Antigua and Barbuda) monitoring suggests modest increases in nesting during recent years as well (M. Clovis-Fuller, Antigua Sea Turtle Project, pers. comm.).

(4) Finally, and in spite of the predation rates we document in this study, there is presently no evidence for a decline in the nesting population at Pasture Bay (Richardson et al. 2006, JBHP Annual Report for 2012, JBHP unpubl. data); rather, the population is thriving and has increase two- to three-fold over the past several decades. However, the most recent estimates indicate that hawksbills in both the Atlantic and Pacific Ocean basins reach sexual maturity in 17 to 22 yr (review: Avens \& Snover 2013). Going back 22 yr, about 30 hawksbills were nesting in Pasture Bay. That number may have been insufficient to attract as many predators to the bay and so predation pressures on the hatchlings may have historically been less than those we find today. If so, then the increase in the number of nesting females observed during the previous years may not be sustained in the future.

In spite of these uncertainties, there is no question that preserving the Pasture Bay matriline is a preferred option, and so an effort should be made to improve those prospects by increasing hatchling production at Pasture Bay. With that end in mind, we recommend that in addition to the monitoring protocols currently in place, a short-term strategy should include the transfer and release of hatchlings from some nests to other locations within the Bay, and to adjacent beach sites on the island where the turtles are known to nest. 'Spreading the spatial risk' is recommended when managing hatcheries (Mortimer 1999); it is also a strategy that was proven effective in 
reducing predation rates at a Florida, USA, hatchery site (Wyneken \& Salmon 1994). Risk-spreading is also promoted by modifying the habitat to make it more suitable for nesting, with the objective that the turtles will distribute their nests more evenly. Efforts to do so are ongoing at Jumby Bay and should be continued by restoring the vegetation canopy behind the beach and selectively thinning sites with invasive Scaevola sericea to create entry 'corridors' (i.e. gaps in the vegetation) for females searching for nesting sites.

We also suggest initiating 2 new research projects. One project should aim to identify and determine the abundance of the hatchling predators and assess their habitat requirements, movements and activity patterns. That knowledge should prove invaluable in the development of strategies to control their impact. A second project should be designed to directly determine what proportion of the hatchlings from controlled releases of entire clutches actually survives to exit the bay. That objective could be accomplished by recaptures of swimming hatchlings minutes later in a shallow net floating at the surface, and anchored across the opening of the bay. A similar technique is used to estimate the abundance of juvenile marine turtles in other shallow water habitats (Ehrhart 1983). These data may also be used to determine whether tracking single turtles (a less laborintensive procedure) provides a reliable estimate of hatchling survival probabilities.

In conclusion, our data indicate that a concentration of nesting sea turtles may lead to circumstances that compromise hatchling survival during offshore migration. Given those circumstances and the Critically Endangered status of hawksbills throughout the Caribbean, we recommend additional management strategies to improve nesting habitat suitability and refine estimates of nesting beach productivity.

Acknowledgements. We are grateful to the National Savethe-Sea-Turtle Foundation of Fort Lauderdale, Florida, USA, for financial support. The Jumby Bay Hawksbill Project, which is generously supported by the Jumby Bay Island Company, provided logistical support. We thank the Jumby Bay Resort for use of their kayaks to survey Pasture Bay and to follow swimming turtles offshore. This study served as a portion of a Master's thesis for M.R. She thanks her committee members (N. Dorn and J. Wyneken) for their advice, guidance and encouragement. Comments by S. Heppell, J. Wyneken, M. J. Saunders, Matthew Godfrey and several referees improved the manuscript. The study design was approved by the Florida Atlantic University IACUC Committee (protocol A12-16) and by the Antigua Division of Fisheries.

\section{LITERATURE CITED}

Abreu A, Leroux R (2007) Hawksbills genetics explained. SWoT Rep 3:16

Andrews HV, Choudhury BC, Shanker K (2003) Sea turtle conservation: beach management and hatchery programmes. GOI-UNDP Project Manual, Centre for Herpetology/Madras Crocodile Bank GTrust, Mamallapuram, Tamil Nadu

Avens L, Snover ML (2013) Age and age estimation in sea turtles. In: Wyneken J, Lohmann KJ, Musick JA (eds) The biology of sea turtles, Vol 3. CRC Press, Boca Raton, FL, p 97-134

Bass AL (1999) Genetic analysis to elucidate the natural history and behavior of hawksbill turtles (Eretmochelys imbricata) in the wider Caribbean: a review and reanalysis. Chelonian Conserv Biol 3:195-199

Beggs JA, Horrocks JA, Krueger BH (2007) Increase in hawksbill sea turtle Eretmochelys imbricata nesting in Barbados, West Indies. Endang Species Res 3:159-168

Cresswell W, Quinn JL (2011) Predicting the optimal prey group size from predator hunting behavior. J Anim Ecol 80:310-319

Crouse DT (1999) Population modelling and implications for Caribbean hawksbill turtle management. Chelonian Conserv Biol 3:185-188

> Ditmer MA, Stapleton SP (2012) Factors affecting hatch success of hawksbill sea turtles on Long Island, Antigua, West Indies. PLoS ONE 7(7):e38472

Ehrhart LM (1983) Marine turtles of the Indian River Lagoon system. Fla Sci 46:337-346

Fuller JE, Eckert KL, Richardson JI (1992) WIDECAST Sea Turtle Recovery Action Plan for Antigua and Barbuda. Eckert KL (ed) CEP Tech Rep 16. UNEP Caribbean Environment Programme, Kingston

- Gyuris E (1994) The rate of predation by fishes on hatchlings of the green turtle (Chelonia mydas). Coral Reefs 13: $137-144$

Harewood A, Horrocks J (2008) Impacts of coastal development on hawksbill hatchling survival and swimming success during their initial offshore migration. Biol Conserv 141:394-401

Heppell SS, Snover M, Crowder LB (2003) Sea turtle population ecology. In: Lutz P, Musick JA, Wyneken J (eds) The biology of sea turtles, Vol 2. CRC Press, Boca Raton, FL, p 275-306

Horrocks JA, Scott NM (1991) Nest site location and nest success in the hawksbill turtle Eretmochelys imbricata in Barbados, West Indies. Mar Ecol Prog Ser 69:1-8

> Ioannou CC, Tosh CR, Neville L, Krause J (2008) The confusion effect: from neural networks to reduced predation risk. Behav Ecol 19:126-130

$>$ Leroux RA, Dutton PH, Abreu-Grobois FA and others (2012) Re-examination of population structure and phylogeography of hawksbill turtles in the Wider Caribbean using longer mtDNA sequences. J Hered 103:806-820

Meylan AB (1999) Status of the hawksbill (Eretmochelys imbricata) in the Caribbean region. Chelonian Conserv Biol 3:177-184

Meylan AB, Donnelly M (1999) Status justification for listing the hawksbill (Eretmochelys imbricata) as critically endangered in the 1996 IUCN Red List of Threatened Animals. Chelonian Conserv Biol 3:200-224

Mortimer JA (1999) Reducing threats to eggs and hatchlings: hatcheries. In: Eckert KL, Bjorndal KA, Abreu- 
Grobois FA, Donnelly M (eds) Research and management techniques for the conservation of sea turtles. IUCN/SSC Marine Turtle Specialist Group Publ 4, p 175-178

Mortimer JA, Donnelly M (2008) Eretmochelys imbricata. In: IUCN 2008. IUCN Red List of Threatened Species version 2010.4. www.iucnredlist.org

NMFS (National Marine Fisheries Service) (2007) Hawksbill sea turtle (Eretmochelys imbricata) 5-year review: summary and evaluation. NMFS, Silver Spring, MD, and US Fish and Wildlife Service, Jacksonville, FL

Pérez-Castañeda R, Salum-Fares A, Defeo O (2007) Reproductive patterns of the hawksbill turtle Eretmochelys imbricata in sandy beaches of the Yucatan Peninsula. J Mar Biol Assoc UK 87:815-824

Pilcher NJ, Enderby S, Stringell T, Bateman L (2000) Nearshore turtle hatchling distribution and predation. In: Pilcher NJ, Ismail G (eds) Sea turtles of the Indo-Pacific: research, management, and conservation. Asean Academic Press, London, p 151-166

Proietti MC, Reisser J, Mrines LF, Rodriguez-Zarate C and others (2014) Genetic structure and natal origins of immature hawksbill turtles (Eretmochelys imbricata) in Brazilian waters. PLoS ONE 9:e88746

Richardson JI, Bell R, Richardson TH (1999) Population ecology and demographic implications drawn from an 11-year study of nesting hawksbill turtles, Eretmochelys imbricata, at Jumby Bay, Long Island, Antigua, West Indies. Chelonian Conserv Biol 3:244-250

Richardson JI, Hall DB, Mason PA, Andrews KM, Bjorkland R, Cai Y, Bell R (2006) Eighteen years of saturation tag-

Editorial responsibility: Matthew Godfrey,

Beaufort, North Carolina, USA ging data reveal a significant increase in nesting hawksbill sea turtles (Eretmochelys imbricata) on Long Island, Antigua. Anim Conserv 9:302-307

Siegel S, Castillan NJ (1988) Nonparametric statistics for the behavioral sciences. McGraw-Hill, New York, NY

Stancyk SE (1982) Non-human predators of sea turtles and their control. In: Bjorndal KA (ed) Biology and conservation of sea turtles. Smithsonian Institution Press, Washington, DC, p 19-38

Stewart KR, Wyneken J (2004) Predation risk to loggerhead hatchlings at a high-density nesting beach in southeast Florida. Bull Mar Sci 74:325-335

Whelan CL, Wyneken J (2007) Estimating predation levels and site-specific survival of hatchling loggerhead seaturtles (Caretta caretta) from South Florida beaches. Copeia 2007:745-754

- Witherington BE (1991) Orientation of hatchling loggerhead sea turtles at sea off artificially lighted and dark beaches. J Exp Mar Biol Ecol 149:1-11

> Witherington BE, Salmon M (1992) Predation on loggerhead turtle hatchlings after entering the sea. J Herpetol 26: 226-228

Witzell WN (1983) Synopsis of biological data on the hawksbill turtle Eretmochelys imbricata (Linnaeus, 1766). FAO Fish Synop 137, Miami, FL

Wyneken J, Salmon M (1994) Aquatic predation, fish densities, and potential threats to sea turtle hatchlings leaving from open-beach hatcheries. Tech Rep 94-11, Broward County Board of Commissioners, Fort Lauderdale, FL

Zar JH (1999) Biostatistical analysis. Prentice-Hall, Upper Saddle River, NJ

Submitted: January 5, 2015; Accepted: October 19, 2015

Proofs received from author(s): December 7, 2015 